\title{
European Venous Forum / EVF Kongress 2019 in Zürich
}

Vom 27. Juni bis 29. Juni 2019 findet der European Venous Forum/EVF Kongress in Zusammenarbeit mit der Schweiz. Gesellschaft für Phlebologie/SGP an der Universität Zürich statt. Die diesjährigen Hauptthemen sind

- Behandlung der Varicosis

- ulcus cruris

- Lymphödem

- Tiefe Venenthrombose/postthrombotisches Syndroms

- Kompressionsbehandlung

Abgesehen von den didactic sessions, den meet the expert sessions über Mittag, der Diskussion von ausgewählten posters und den industry sessions, liegt der Schwerpunkt - wie in den Zielen des EVF vorgegeben - auf den freien Mitteilungen (abstract sessions), die à fond diskutiert werden: „the time devoted to discussion is more than the time devoted to the actual presentations".

Erstmals wird eine gemeinsame Sitzung des American Venous Forum und dem European Venous Forum durchgeführt, ein Zeichen dafür, dass AVF und EVF in den kommenden Jahren eine engere Zusammenarbeit anstreben.

Der diesjährige Kongress ist ein Jubiläumskongress: Vor 20 Jahren wurde das EVF in Lyon gegründet. Michel Perrin aus Frankreich war der erste Kongresspräsident „I was very happy to serve as president of the inaugural EVF meeting“, sagt er im Rückblick. Andrew Nicolaides fungierte als general secretary. In den folgenden Jahren ist das European Venous Forum quer durch Europa „gezogen“ und ist nun 2019 zum ersten Mal auch in der Schweiz. Mit dem Ziel „education, scientific knowledge, research and clinical expertise of the highest quality and establish standards in the field of venous disease" werden neben den jährlichen Meetings seit 2010 auch die mehrtägigen EVF How Kurse (100 Teilnehmer) und seit 2015 die meist eintägigen EVF How Plus Kurse

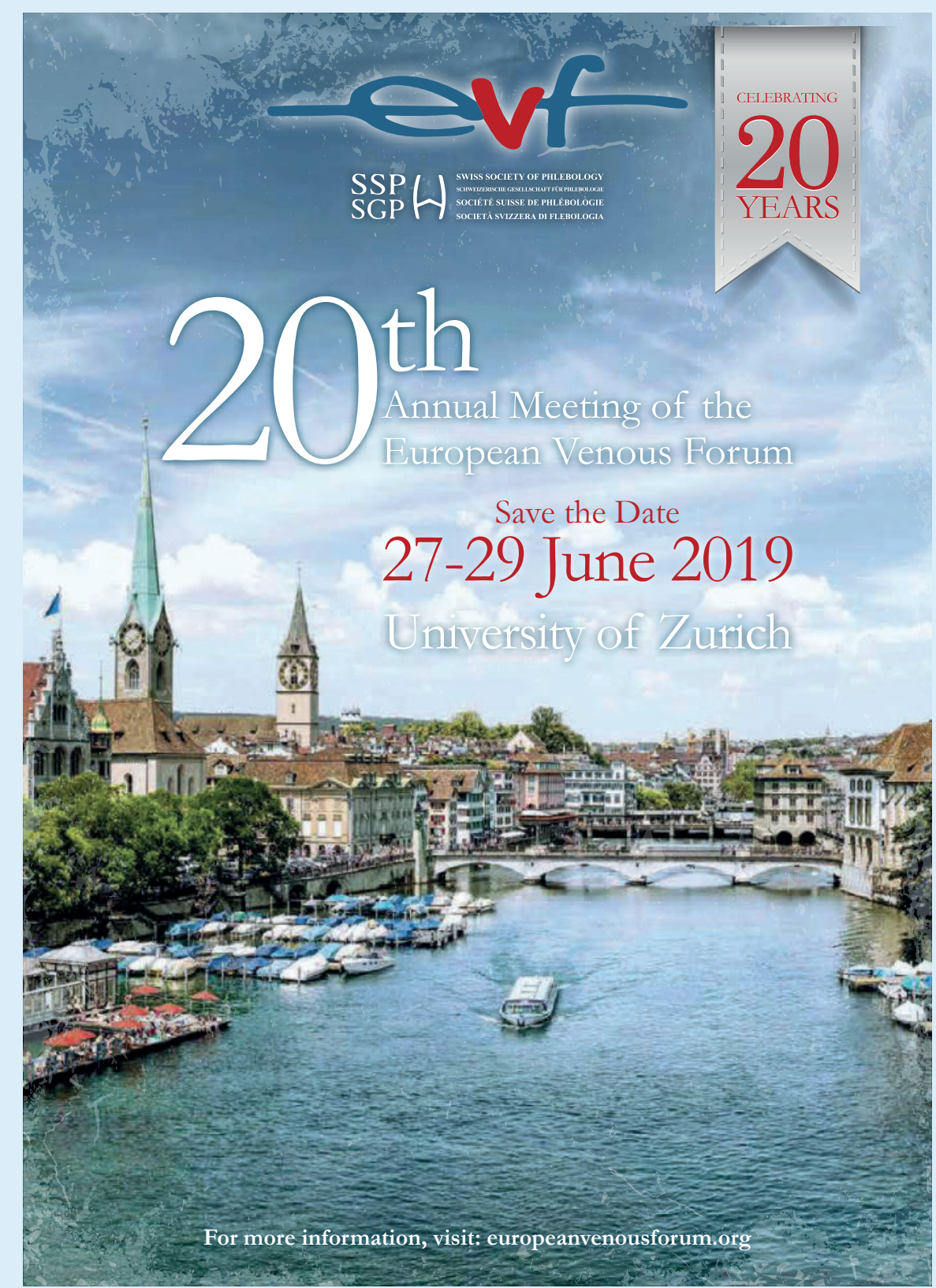

(4-18 Teilnehmer) zu einem ganz spezifischen Thema angeboten. Das EVF ist seit ihrer Gründung eine sehr aktive Gesellschaft mit enthusiastischen Mitgliedern, und seine Kongresse und workshops erfreuen sich zunehmender Beliebtheit mit ständig steigenden Teilnehmerzahlen.
Happy birthday, EVF, und Willkommen in Zürich.

Für weitere Details und für die Kongressregistrierung verweisen wir auf www.europeanvenousforum.org.

IMPRESSUM

Verantwortlich für Mitteilungen der SGP:

Prof. Dr. med.

Christina Jeanneret-Gris, Bruderholz 